\title{
UJARAN KEBENCIAN (HATE SPEECH) DI MASYARAKAT DALAM KAJIAN TEOLOGI
}

\author{
Zulkarnain \\ Universitas Islam Negeri Sumatera Utara (UINSU) Medan \\ zul.karnain@uinsu.ac.id
}

\begin{abstract}
Abstrak
Perkembangan media sosial yang sudah canggih dapat memposting konten berupa tulisan, video, suara maupun gambar secara bebas yang dapat disebarluaskan dimanapun dan kapanpun dengan bantuan jaringan internet. Tidak jarang pengguna media sosial menyalahgunakan media sosial sebagai sarana untuk meluapkan emosi mereka, menyebar berita palsu, menjatuhkan orang lain, bahkan menyebar kebencian kepada orang lain atau suatu kelompok. Tidak sedikit masyarakat yang merasa dirugikan akibat dari ujaran kebencian ini. Tujuan penulis mengangkat fenomena ini adalah untuk mengetahui bagaimana ujaran kebencian (hate speech) di masyarakat menurut kajian teologi. Secara metodologis, Penelitian ini menggunakan jenis penelitian kualitatifdengan pendekatan kepustakaan (library research). Faktor yang menjadi penyebab pelaku melakukan ujaran kebencian (hate speech) yaitu, faktor dari dalam diri individu (internal) diantaranya yaitu keadaan psikologis dan kejiwaan individu dan faktor dari luar diri individu yaitu faktor lingkungan, faktor kurangnya kontrol sosial, faktor kepentingan masyarakat, faktor ketidaktahuan masyarakat, serta faktor sarana, fasilitas dan kemajuan teknologi dan psikologis atau kejiwaan pelaku yaitu daya emosional yang tinggi, selain itu faktor sarana, fasilitas dan kemajuan teknologi juga sangat berpengaruh karena tersedianya sarana dan fasilitas yang mudah didapat dan kemajuan teknologi yang semakin canggih sehingga memudahkan setiap pengguna media sosial mengakses seluruh informasi tanpa batas. Upaya penanggulangan terjadinya kejahtan ujaran kebencian (bate speech) dalam media sosial yaitu terdiri dari upaya penal dan non penal. Dimana upaya penal terdiri dari pemberian sanksi kepada pelaku dengan memberikan hukuman penjara sesuai dengan apa yang telah ditetapkan dalam UU ITE untuk memberikan efek jera. Sedangkan upaya non penal yaitu dengan memberikan penyuluhan ataupun sosialisasi kepada masyarakat luas mengenai informasi dampak media elektronik jika tidak digunakan dengan bijak, etika menggunakan media sosial dengan memberikan pengetahuan hukum mengenai UU ITE.
\end{abstract}

Kata Kunci: Ujaran, Kebencian, Masyarakat, Teologi

\section{Abstract}

The development of sophisticated social media can post content in the form of text, video, sound and images freely which can be disseminated anywhere and anytime with the help of the internet network. Not infrequently social media users abuse social media as a means to vent their emotions, spread false news, bring down others, and even spread hatred to other people or groups. Not a few people who feel disadvantaged as a result of this bate speech. The author's purpose in raising this phenomenon is to find out how bate speech (bate speech) is in society according to theological studies. Methodologically, this study uses a qualitative research type with a library research approach. The factors that cause the perpetrators to do bate speech (bate speech), namely, factors from within the individual (internal) including the psychological and psychological condition of the individual and factors from outside the individual, namely environmental factors, factors of lack of social control, factors of community interest, factors of ignorance community, as well as facilities, facilities and 
technological and psychological or psychological progress of the actors, namely high emotional power, besides the factors of facilities, facilities and technological progress are also very influential because of the availability of facilities and facilities that are easily available and increasingly sophisticated technological advancements making it easier for each social media users access all information without limits. Efforts to overcome the occurrence of hate speech (hate speech) crime in social media that consists of penal and non-penal efforts. Where penalties consist of imposing sanctions on perpetrators by imprisonment in accordance with what has been stipulated in the ITE Law to provide a deterrent effect. While the non-penal effort is to provide counseling or outreach to the general public regarding information on the impact of electronic media if not used wisely, the etbics of using social media by providing legal knowledge about the ITE Law.

Keywords: Speech, Hate, Society, Theology

\section{Pendahuluan}

Perkembangan teknologi informasi dan komunikasi saat ini meningkat pesat dari tahun ke tahun. Tuntutan perkembangan zaman menjadikan kebutuhan teknologi masyarakat semakin bertambah. Berbagai produk teknologi yang semakin canggih untuk memenuhi kebutuhan masyarakat yang konsumtif diciptakan. Hal ini merupakan wujud dari berkembangnya zaman teknologi informasi dan komunikasi yang kuno menuju zaman teknologi informasi dan komunikasi yang lebih modern agar dapat menyesuaikan dengan perkembangan zaman yang disebut dengan era globalisasi.

Pesatnya perkembangan teknologi informasi dan komunikasi ini bisa dilihat dalam kehidupan sehari-hari. Pada zaman dahulu masyarakat menggunakan surat, telegram, radio, koran, majalah, dan lain sebagainya sebagai alat yang memfasilitasi mereka untuk mencari informasi dan berkomunikasi. Bahkan untuk berkomunikasi jarak jauh saja membutuhkan waktu yang relatif lama. Dengan adanya perkembangan teknologi informasi dan komunikasi ini, sekarang masyarakat tidak perlu direpotkan dengan sulitnya berkomunikasi dan mencari informasi walaupun ada perbedaan jarak sekalipun.

Di era globalisasi ini, media massa mempunyai peranan penting dalam hal berkomunikasi dan berbagi informasi. Media massa adalah sarana dan saluran resmi sebagai alat komunikasi untuk menyebarkan berita dan pesan kepada masyarakat luas. Masyarakat dapat menggunakan media massa dengan bantuan jaringan internet sebagai alat mencari informasi dan berkomunikasi secara bebas. Mulai dari mencari dan menyebarkan berita, ilmu pengetahuan, bahkan berkomunikasi di media sosial.

Peerkembangan media sosial yang sudah canggih dapat memposting konten berupa tulisan, video, suara maupun gambar secara bebas yang dapat disebarluaskan dimanapun dan kapanpun dengan bantuan jaringan internet. Tidak jarang pengguna media sosial menyalahgunakan media sosial sebagai sarana untuk meluapkan emosi mereka, menyebar berita palsu, menjatuhkan orang lain, bahkan menyebar kebencian kepada orang lain atau suatu kelompok. 
Ujaran Kebencian (Hate Speech) adalah tindakan komunikasi yang dilakukan oleh suatu individu atau kelompok dalam bentuk provokasi, hasutan, ataupun hinaan kepada individu atau kelompok lain dalam hal berbagai aspek seperti ras, warna kulit, gender, cacat, orientasi seksual, kewarganegaraan, agama dan lain-lain.

Ujaran kebencian yang dilayangkan kepada seseorang atau kelompok orang tertentu banyak mencuri perhatian akhir-akhir ini. Melalui postingan di media sosial dengan ujaran kebencian semakin marak diperbincangkan. Banyak pengguna internet (netizen) menyebarluaskan suatu postingan (gambar, foto, video, suara, dan kata-kata) dengan ujaran kebencian yang menimbulkan penghinaan, pencemaran nama baik, penistaan agama, dan lain sebagainya.

Ujaran kebencian tidak hanya dilakukan di media massa maupun media sosial saja. Banyak peristiwa ujaran kebencian yang dilakukan selain pada media tersebut. Ujaran kebencian bisa juga dilakukan saat seseorang atau lebih berorasi di depan publik, ceramah keagamaan, bahkan lewat tulisan berupa spanduk maupun banner.

Tidak sedikit masyarakat yang merasa dirugikan akibat dari ujaran kebencian yang sedang marak terjadi ini melakukan upaya politik. Penggunaan upaya politik, termasuk politik pidana sebagai salah satu upaya untuk mengatasi masalah sosial termasuk dalam bidang kebijakan penegakan politik. Di samping itu karena tujuannya adalah untuk mencapai kesejahteraan masyarakat pada umumnya, maka kebijakan penegakan politik itupun termasuk dalam bidang kebijakan sosial, yaitu segala usaha yang rasional untuk mencapai kesejahteraan masyarakat.

Ujaran kebencian dapat berupa tindak pidana yang diatur dalam Kitab Undang-Undang Hukum Pidana (KUHP) dan ketentuan pidana lainnya di luar KUHP, yang berbentuk antara lain:

1. Penghinaan;

2. Pencemaran nama baik;

3. Penistaan;

4. Perbuatan tidak menyenangkan;

5. Memprovokasi;

6. Menghasut;

7. Penyebaran berita bohong;

Masyarakat bagaikan dalam satu keping uang logam, berbeda akan tetapi tidak dapat dipisahkan satu dengan yang lain atas keberadaan politik tanpa adanya masyarakat tidaklah berguna, begitu pula sebaliknya, keberadaan masyarakat tanpa adanya politik dapat menghancurkan masyarakat itu sendiri.

Masyarakat yang beragam tentu menimbulkan munculnya kepentingan-kepentingan yang beragam pula. Karena itulah dalam masyarakat diperlukan adanya pengaturan berbagai kepentingan 
yang ada, agar kepentingan-kepentingan itu tidak saling berbenturan satu dengan yang lain. Di sinilah politik berperan, politik dibuat dalam rangka menciptakan kepastian, keadilan dan kemanfaatan bagi masayarakat. Kepastian politik tanpa didasarkan pada sendi-sendi keadilan akan menimbulkan ketidakpuasan dan mengundang banyak reaksi.

Namun, perkembangan teknologi tidak hanya berupa memberikan dampak positif saja, namun juga memberikan dampak negatif, tindak pidana penghinaan atau ujaran kebencian (hate speech) dan/atau penghinaan, serta penyebaran informasi di media sosial yang ditujukan untuk menimbulkan rasa kebencian atau permusuhan antar individu dan/atau kelompok masyarakat tertentu berdasarkan atas suku, agama, ras dan antargolongan (SARA). Tindak pidana tersebut selain menimbulkan dampak yang tidak baik juga dapat merugikan korban dalam hal pencemaran nama baik, dengan modus operandi menghina korban dengan menggunakan kata-kata maupun gambar yang memiliki kata yang menghina dengan ujaran kebencian. Sehingga dalam kasus ini diperlukan adanya ketegasan pada tindak pidana tersebut, agar tidak terjadi kesalahpahaman yang akhirnya merugikan masyarakat.

Sejumlah penelitian mengenai ujaran kebencian (hate speech) diantaranya: Hate Speech Dan Pengaruhnya Terhadap Mentalitas Elite Politik (Andara Soemantri, 2014). Hate Speech di Kalangan Generasi Modern (Medira Hanim, 2016).

Namun, meskipun penelitian ujaran kebencian (hate speech) di atas mengarah kepada kehidupan sosial, belum terlihat jelas mengenai ujaran kebencian di masyarakat dalam kajian teologi. Mempertimbangkan kesenjangan dalam literatur yang ada, penelitian ini dilakukan untuk menjawab pertanyaan "Bagaimana Ujaran Kebencian (Hate Speech) di masyarakat dalam kajian teologi?". Diharapkan penelitian ini berkontribusi untuk mengisi kesenjangan yang disebutkan sebelumnya dan memberikan banyak referensi kepada khazanah keilmuan, khususnya mereka yang berada dalam konsentrasi sosial keagamaan (Social Religion).

\section{Metodologi}

Jenis penelitian yang digunakan dalam penelitian ini adalah kualitatif. Studi pustaka yang akan mengkaji ujaran kebencian (hate speech) di masyarakat dalam kajian teologi. Penerapan kajian teologi dalam pembahasan ini diharapkan mengasilkan solusi (Muhammad Nazir, 1998 : 62).

Sumber data pada penelitian ini meliputi data yang langsung dikumpulkan dari sumber pertama, yaitu karya-karya yang berkenaan dengan tema penelitian.

Metode pengumpulan data dilakukan dengan penelitian kepustakaan (Library Research) (Komaruddin, 1994 : 145) terhadap naskah-naskah dan tulisan-tulisan mengenai ujaran kebencian dalam kajian teologi. Data akan diperoleh dengan cara menelaah dan memahami teks dan keadaan masyarakat. 
Data yang diperoleh akan dianalisis dengan cara analisis isi (Content Analysis) (Muhadjir, 1996 : 49) melalui pendekatan induktif dan deduktif. Penggunaan teknik analisis ini bertujuan untuk menganalisa makna yang terkandung dalam keseluruhan gagasan terutama yang berhubungan dengan judul penelitian di atas.

\section{Hasil dan Pembahasan}

Ujaran kebencian (hate speech) adalah "tidakan komuniksi yang dilakukan oleh suatu individu atau kelompok dalam bentuk provokasi, hasutan, ataupun hinaan kepada individu atau kelompok yang lain dalam hal berbagai aspek seperti ras, warna kulit, gender, cacat, orientasi seksul kewarganegaraan, agama dn lain-lain. Dalam arti hokum ujaran kebencian adalah perkataan, perilku, tulisan, ataupun pertunjukan yang dilarang karena dapat memicu terjadinya tindk kekerasan dan sikap prasangka, baik dari pihak pelaku pernyataan tersebut ataupun korban dari tindakan tersebut (Yudha Prawira, $2016: 5)$.

Kejahatan ujaran kebencian diatas dapat dilakukan melalui berbgai media, antara lain dalam orasi kegiatan kampanye, spanduk atau banner, jejaring media social, penyampaian pendapat dimuka umum, ceramah keagamaan, media masa cetak ataupun elektronik (Yudha Prawira, 2016 : 7).

Kata "bate speech" atau dalam Bahasa Indonesia sering disebut "ujaran kebencian" adalah istilah yang berkaitan erat dengan minoritas dan masyarakat asli, yang menimpa suatu komunitas tertentu dan dapat menyebabkan mereka sangat menderita, sementara orang yang lain tidak peduli. Ia dapat memunculkan penderitaan pisikis maupun fisikk, yang dalam prakteknya banyak menimpa kelompok minoritas dan masyarakat asli. Beberapa contoh trakhir menunjukkan bahwa ujaran kebencian telah menimbulkan kekerasn terhadap kelompok tertentu, seperti pada Kristen katolik di Mesir, masyarakat Muslim di Miyanmar dan para Imigran di Yunani, serta peristiwa genosida di Rwnda yang hingga kini terus diperingati sebagai salah satu kejahatan kemanusiaan terpenting dalam sejarah dunia modern.

Para kritikus berpendapat bahwa istilah hate speech merupakan contoh modern dari novel Newspek. Ketika hate speech dipakai untuk memberikan kritik secara diam-diam kepada kebijakann social yang di implementasikan dengan buruk dan terburu-buru seakan-akan kebijakan tersebut terlihat benar secara politik. Sampai saat ini, belum ada pengertian atau defenisi secara hokum mengenai apa yang disebut hate speech dan pencemaran nama baik dalam Bahasa Indonesia (Moh. Putra Pradipta, 2016 : 28).

Dalam Bahasa Inggris, pencemaran nama baik diartikan sebagi demafation, libel, dan slander yang jika diterjemahkan kedalam Bahasa Indonesia adalah fitnah (demafation), fitnh lisan (libe), fitnah tertulis (slander), dalam Bahasa Indonesia, belum ada kata yang sah untuk membedakan ketiga kata 
tersebut. Hampir semua negara diselruh Dunia mempunyai undang-undang yang mengatur tentang bate speech (Moh. Putra Pradipta, 2016 : 28).

Melihat bahwa persoalan mengenai ujaran kebencian semakin mendapatkan perhatian masyarakat baik nasional maupun internasional seiring dengan meningkatnya kepedulian terhadap perlindungan atas hak asasi manusia, karena mempunyai dampak yang merendahkan harkat dan martabat manusia dan kemanusian (Moh. Putra Pradipta, 2016 : 28).

\section{Macam-Macam Ujaran Kebencian}

Dalam arti hukum Ujaran Kebencian (Hate Speech) adalah perkataan, perilaku, tulisan, ataupun pertunjukan yang dilarang karena dapat memicu terjadinya tindakan kekerasan dan sikap prasangka entah dari pihak pelaku pernyataan tersebut ataupun korban dari tindakan tersebut. Website yang menggunakan atau menerapkan Ujaran Kebencian (Hate Speecb)ini disebut (Hate Site). Kebanyakan dari situs ini menggunakan Forum Internet dan Berita untuk mempertegas suatu sudut pandang tertentu (Sutan, 2009 : 38).

Hampir semua Negara diseluruh Dunia mempunyai undang-undang yang mengatur tentang Ujaran Kebencian (Hate Speech), di Indonesia Pasal-Pasal yang mengatur tindakan tentang Ujaran Kebencian (Hate Speech) terhadap seseorang, kelompok ataupun lembaga berdasarkan Surat Edaran Kapolri No: SE/06/X/2015 terdapat di dalam Pasal 156, Pasal 157, Pasal 310, Pasal 311, kemudian Pasal 28 jis.Pasal 45 ayat (2) UU No 11 tahun 2008 tentang informasi \& transaksi elektronik dan Pasal 16 UU No 40 Tahun 2008 tentang penghapusan Diskriminasi Ras dan Etnis (www.suduthukum.com).

Selama ini, Ujaran Kebencian (Hate Speech) berdampak pada pelanggaran HAM ringan hingga berat. Selalu awalnya hanya kata-kata, baik di media sosial, maupun lewat selebaran, tapi efeknya mampu menggerakan massa hingga memicu konflik dan pertumpahan darah. Oleh sebab itu maka di perlukan adanya suatu tindakan dari para aparat dan penegak hukum khususnya Kepolisian untuk mencegah dan melakukan tindakan preventif maupun represif dalam menangani kasus Ujaran Kebencian (Hate Speech) ini. Apabila tidak ditangani dengan efektif efisien dan sesuai dengan ketentuan peraturan perundangundangan akan berpotensi memunculkan konflik sosial yang meluas, dan berpotensi menimbulkan tindak diskriminasi, kekerasan dan atau penghilangan nyawa.

Didalam Surat Edaran Kapolri NOMOR SE/06/X/2015 tentang Ujaran Kebencian (Hate Speech). Nomor 2 huruf (f) Surat Edaran Kapolri Nomor SE/06/X/2015 menyebutkan: Ujaran kebencian dapat berupa tindak pidana yang diatur dalam Kitab Undang-Undang Hukum Pidana (KUHP) dan ketentuan pidana lainnya di luar KUHP, yang berbentuk antara lain:

1. Penghinaan. 
2. Pencemaran nama baik.

3. Penistaan.

4. Perbuatan tidak menyenangkan

5. Memprovokasi

6. Menghasut

7. Menyebarkan berita bohongdan semua tindakan di atas memiliki tujuan atau bisa berdampak pada tindak diskriminasi, kekerasan, penghilangan nyawa, dan atau konflik sosial (www.suduthukum.com).

Ujaran kebencian (hate speech) sebagaimana dimaksud di atas, bertujuan untuk menghasut dan menyulut kebencian terhadap individu dan atau kelompok masyarakat, dalam berbagai komunitas yang dibedakan dari aspek:

1. Suku

2. Agama

3. Aliran keagamaan

4. Keyakinan atau kepercayaan.

5. Ras

6. Antar golongan.

7. Warna kulit

8. Etnis

9. Gender

10. Kaum difabel

11. Orientasi seksual

Ujaran kebencian sebagaimana dimaksud di atas dapat dilakukan melalui berbagai media, antara lain:

1. Dalam orasi kegiatan kampanye

2. Spanduk atau banner

3. Jejaring media sosial

4. Penyampaian pendapat di muka umum (demonstrasi)

5. Ceramah keagamaan

6. Media masa cetak atau elektronik

7. Pamflet 
Persoalan ujaran kebencian (bate speech) semakin mendapatkan perhatian masyarakat baik nasional maupun internasional seiring dengan semakin meningkatnya kepedulian terhadap perlindungan hak asasi manusia (HAM), karenanya tidak heran jika Kapolri mengeluarkan surat edaran tersebut. Potensi terbesar dan merupakan sumber terbesar pemicu ujaran kebencian (hate speech) yaitu melalui media sosial seperti twitter, facebook, dan blog-blog independent, yang keberadaanya merupakan inovasi terbesar pada awal abad 21 ini. Media sosial tidak hanya sebagai media penghubung dan berbagi, media sosial juga mampu melakukan sebuah perubahan besar yang sering digunakan dalam bidang politik dan bidang yang lainnya.

\section{Faktor Penyebab Ujaran Kebencian}

Ujaran kebencian sudah menjadi tranding topik diberbagai media massa. Kasus ujaran kebencian di Indonesia dapat dikatakan dalam kondisi awas, karena banyak kasus yang telah ditemukan. Adapun faktor-faktor penyebab pelaku melakukankejahatan ujaran kebencian (hate speech) adalah sebagai berikut:

1. Faktor individu/pribadi

Faktor kejiwaan individu itu sendiri dapat menyebabkan kejahatan seperti daya emosional, rendahnya mental, sakit hati dengan korban, dendam, dan lainnya.

2. Faktor Ketidaktahuan Masyarakat

Faktor ketidaktahuan masyarakat juga merupakan penyebab terjadinya tindak kejahatan ujaran kebencian (bate speech). Kurangnya sosialisasi/penyuluhan kepada masyarakat inilah yang menyebabkan kejahatan ini terjadi di masyarakat yang tergolong tidak tahu akan adanya aturan mengenai kejehatan ujaran kebencian (hate speech) khususnya penghinaan.

3. Faktor sarana dan fasilitas

Faktor sarana dan fasilitas juga berpengaruh pada era globalisasiseperti saat sekarang ini, dan itu juga berpengaruh pada tumbuh pesatnyamedia elektronik khususnya media internet sehingga penyebaran informasi semakin mudah, cepat dan efektif untuk didapatkan. Sehingga seseorang kurang bijaknya menggunakan sarana media internet ataupun komunikasi serta tidak ada batasan dalam penggunaan alat komunikasi.

4. Faktor kurangnya kontrol sosial

Faktor kurangnya kontrol sosial yaitu kurangnya kontrol internal yang wajar dari pihak atau lingkungan dalam keluarga yang seringkali tidak mau tahu akan kondisi anggota keluarganya tersebut, dan dari pihak eksternal yang mana masyarakat tidak memperdulikan akan kejadian-kejadian kejahatan yang terjadi di sekitarnya, hilangnya kontrol tersebut dan tidak adanya norma- norma sosial atau konflik norma- norma yang dimaksud. 
5. Faktor lingkungan

Lingkungan adalah tempat utama dalam mendukung terjadinya polaprilaku kejahatan yang dilakukan oleh seseorang. Faktor-faktor yang mempengaruhi tersebut antara lain adalah lingkungan yang memberi kesempatan untuk melakukan kejahatan dan lingkungan pergaulan yang memberi contoh dan teladan.

6. Faktor ekonomi dan kemiskinan

Ekonomi sangat mempengaruhi pula terjadinya kejahatan ujaran kebencian (bate speech). Faktor ekonomi yang dapat memicu terjadinya kejahatan biasanya bermula dari keadaan ekonomi pelaku yang tergolong rendah, pengangguran, tidak berpenghasilan dan terdesak akan suatu kebutuhan- kebutuhan yang tinggi serta mendesak sehingga mendorong pelaku melakukan kejahatan ujaran kebencian (bate speech).

7. Faktor kepentingan masyarkat

Masyarakat cenderung tidak memikirkan dampak apa yang akan terjadi dikemudian hari dengan melakukan kejahatan uajaran keencian (hate speech) dalam media sosial. Banyak masyarakat yang melakukan ujaran kebencian karena memiliki tujuan tertentu diantaranya mengenai hal pribadi, Politik, SARA maupun hanya sekedar ingin dikenal banyak orang (Mery Febriyani, 2018 : 7-15).

Berdasarkan hasil uraian mengenai faktor-faktor penyebab pelaku melakukan kejahatan ujaran kebencian (hate speech) berupa penghinaan, bahwa pada dasarnya perlu diketahui terhadap perbuatan jahat yang dilakukan oleh seseorang seringkali dilakukan oleh seseorang dengan maksud dan tujuan yang berbeda-beda sesuai dengan faktor- faktor yang mempengaruhi bagi tiap- tiap individu tersebut. Bahwa pada artinya masih banyak terdapat faktor- faktor penyebab lainnya yang membuat seseorang melakukan kejahatan ujaran kebencian (hate speech) berupa penghinaan yang dilakukan.

\section{Ujaran kebencian (hate speech) dalam kajian teologi}

Dalam bahasa Arab, ujaran kebencian disebut dengan خطاب انكثَاْيةadapun kata كشِ dalam penggunaannya sangat majemuk. Bisa dikaitkan dengan bahasa, agama maupun ahlak. Sebagaimana

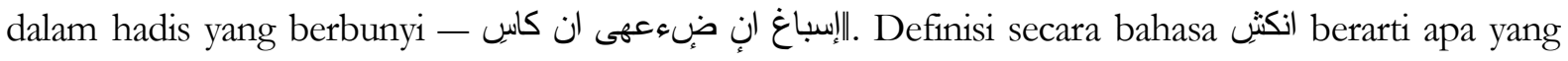

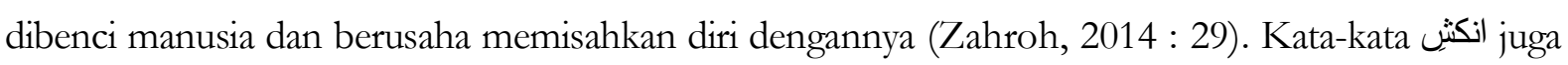

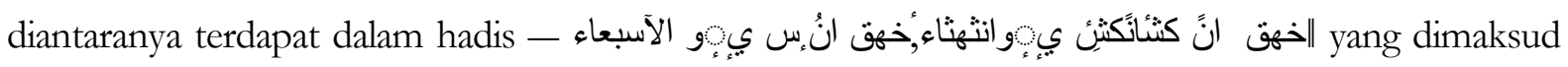
makruh dalam hadis tersebut adalah kejelekan. Adapun secara istilah maka kata كثي mempunyai hubungan dengan makna sebagai berikut: ((Zahroh, 2014 : 29)

1. Kebencian manusia dengan kekuatan terhadap pekerjaan yang tidak mampu dan disukainya

2. Kebencian dimaknai keburukan dan menjadi lawan kata dari yang disukai atau kebaikan 
3. كثكشِ dimaknai juga menganjurkan manusia kepada kebencian atau hal lain yang merupakan kebalikan dari yang disukai. Atau dengan kata lain memaksa untuk membenci.

4. كثناْيْة dimaknai hal yang buruk.

Dari berbagai pengertian di atas, maka dapat dimengerti tentang definisi خطاب انكثنأْية yang dipakai dalam media arab, yaitu menghasut dan menganjurkan kebencian kepada yang lain. Adapun yang perlu di garis bawahi adalah tentang dua hal yang penting dalam ujaran kebencian pertama yaitu kebencian dan hasutan. Al-Hikdu dapat dimaknai sebagai menahan rasa permusuhan dalam hati dan mengeluarkannya pada kesempatan yang tepat. Adapun kata al-Tahrid yaitu menganjurkan orang lain dimana orang tersebut mengetahui penganjurnya (Zahroh, 2014 : 30).

Dalam Islam membenci sesama adalah suatu perbuatan yang tercela. Sebagaimana terdapat dalam sebuah hadis dari Anas, bahwasanya Rasulullah bersabda:

"Tanganlah engkau semua saling benci-membenci, saling dengki-mendengki,salingbelakang-membelakangi dan saling putus-memutuskanikatan persahabatan atau kekeluargaandan jadilah engkau semua hai namba-hamba Allah sebagai saudara-saudara. Tidaklah halal bagi seseorang Muslim kalau ia meninggalkanyakni tidak menyapasaudaranya lebih dari tiga hari (MuttafaqAlaibi) (Yahya, 1987 : 426).

Diriwayatkan dari Abu Hurairah, bahwasanya Rasulullah bersabda: "Pintu surga dibuka setiap hari Senin dan Kamis. Maka pada hari itu setiap hamba diberi ampunan selama ia tidak menyekutukan Allah dengan sesuatu apapun, kecuali seorang hamba yang bermusuban dengan saudaranya. Maka dikatakan, 'Akbirkan dulu mereka bingga mereka akur, akbirkan dulu mereka bingga mereka akur, akbirkan dulu mereka bingga mereka akur, akbirkean dulu mereka bingga merek a akur" (HR. Muslim) (Yahya, 1987 : 437).

Dari Abdullah binAmr bin Ash RA. ia berkata: Rasulullah Saw. bersabda: "Orang Islam adalah kaum mukminin yang terbindar dari gangguan lidah dan tangannya; sedangkan orang yang bijrah adalah orang yang meninggalkan segala apa yang dilarang Allab"(Muttafaq Alaibi) (Yahya, 1987 : 437).

Selain larangan untuk membenci sesama umat Islam, sifat rahmatan lil" alamin juga berlaku bagi umat yang lain. Hal tersebut sebagaimana dalam al Quran disebutkan:

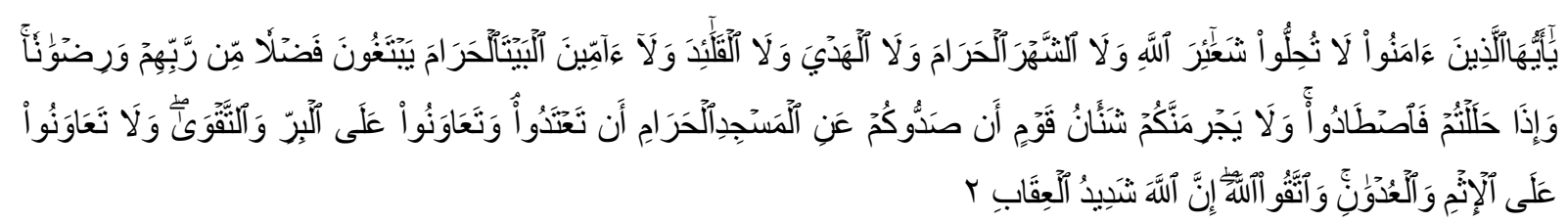

Artinya: Hai orang-orang yang beriman, janganlah kamu melanggar syi'ar-syi'ar Allah, dan jangan melanggar kehormatan bulan-bulan haram, jangan (mengganggu) binatang-binatang had-ya, dan binatang-binatang qalaa-id, dan jangan (pula) mengganggu orang-orang yang mengunjungi Baitullah sedang mereka mencari kurnia dan keridhaan dari Tuhannya dan apabila kamu telah menyelesaikan ibadah haji, maka boleblab berburu. Dan janganlah sekali-kali kebencian(mu) kepada sesuatu kaum karena mereka menghalang-halangi kamu dari Masjidilharam, mendorongmu berbuat aniaya (kepada mereka). Dan tolong-menolonglah kamu dalam (mengerjakan) kebajikean dan takwa, dan jangan tolong-menolong dalam berbuat dosa dan pelanggaran. Dan bertakwalah kamu kepada Allah, sesunggubnya Allah amat berat siksa-Nya. (Al-Maidah ayat 2). 
Pada ayat lain diterangkan,

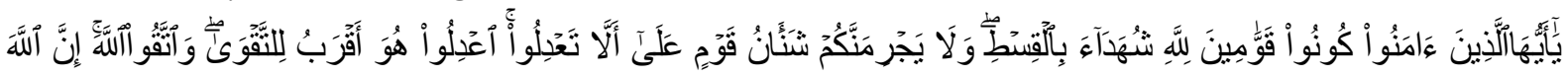

خَبِيرُ بِمَا نَعَعَلُونَنَ

Artinya: Hai orang-orang yang beriman hendaklah kamu jadi orang-orang yang selalu menegakean (kebenaran) karena Allah, menjadi saksi dengan adil. Dan janganlah sekali-kali kebencianmu terhadap sesuatu kaum, mendorong kamu untuk. berlaku tidak adil. Berlaku adillah, karena adil itu lebih dekat kepada takwa. Dan bertakwalab kepada Allah, sesunggubnya Allah Maha Mengetabui apa yang kamu kerjakan. (Al Maidah ayat 8).

Berkaitan dengan bate speech, maka kebencian yang dilarang dalam Islam termasuk perkataan

buruk yang dapat menyakiti orang lain. Adapun diantara ayat-ayatnya adalah sebagai berikut:

1. Al- Anam ayat 108

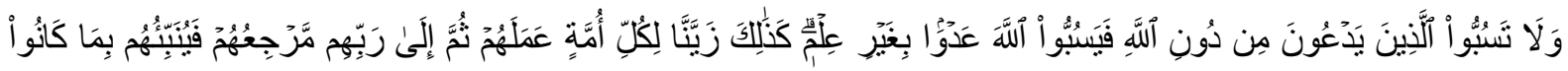

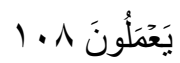

Artinya: "Dan janganlah kamu memaki sembahan-sembahan yang mereka sembah selain Allah, Karena mereka nanti akan memaki Allah dengan melampaui batas tanpa pengetabuan. Demikianlab kami jadikan setiap umat menganggap baik pekerjaan mereka. Kemudian kepada Tuban merekalah kembali mereka, lalu dia memberitakan kepada mereka apa yang dabulu mereka kerjakan”. (Al- Anam ayat 108)

2. Al-Hujrat ayat 11 dan 12

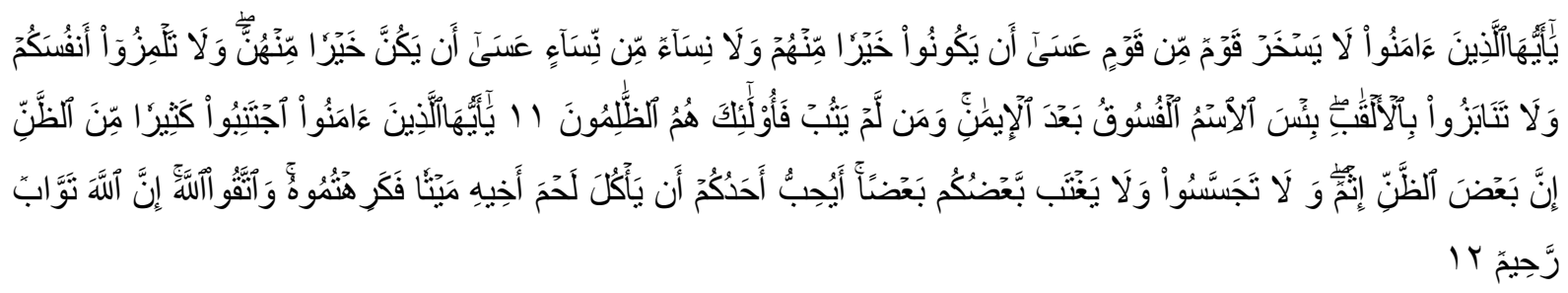

Artinya: Hai orang-orang yang beriman, janganlah sekumpulan orang laki-laki merendabkan kumpulan yang lain, boleh jadi yang ditertawakan itu lebib baik dari mereka. Dan jangan pula sekumpulan perempuan merendabkan kumpulan lainnya, boleh jadi yang direndabkan itu lebih baik. Dan janganlah suka mencela dirimu sendiri dan jangan memanggil dengan gelaran yang mengandung ejekan. Seburuk-buruk, panggilan adalah (panggilan) yang buruk sesudah iman dan barangsiapa yang tidak bertobat, maka mereka itulah orang-orang yang zalim (11). Hai orang-orang yang beriman, jaubilah kebanyakan purba-sangka (kecurigaan), karena sebagian dari purba-sangka itu dosa. Dan janganlah mencari-cari keburukan orang dan janganlah menggunjingkan satu sama lain. Adakah seorang diantara kamu yang suka memakan daging saudaranya yang sudah mati? Maka tentulah kamu merasa jïike kepadanya. Dan bertakwalah kepada Allah. Sesunggubnya Allah Maha Penerima Taubat lagi Maha Penyayang (12).

Dalam tafsir al-Manar dijelaskan bahwa الإسخاس bermakna الإحتقاس أ الإستَّضاء yaitu menghina dan menganggap remeh. Adapun انًََض berarti mencela dan melaknat dengan maksud menyakiti. انَّاص dilakukan dengan perkataan adapun dengan perbuatan. Terkahir adalah انتُابض yaitu panggilan yang tidak pantas, dimana manusia yang mendengarnya merujuk kepada sesuatu yang buruk/jelek (Imamuddin Abi al-Fida Isma’il Ibnu Kastsir, 2000 : 154). 
Dalam Islam, formulasi tindakan hate speech melebihi cakupan dalam definisi regulasi maupun istilah Barat. Asas moral yang mendasari hate speech berlaku bagi tindakan lain yang berkaitan dengan kemaslahatan umat. Pertama larangan untuk membenci orang lain, sesama muslim ataupun non muslim. Secara subjektif seorang muslim dilarang untuk memiliki perasaan hasad ataupun melakukan tindakan atas kebenciannya kepada orang lain. Adapun dari sudut objektif, maka tindakan apapun yang menyakiti orang lain dilarang oleh agama.

Kedua spesifik hate speech, maka berkaitan dengan larangan perkataan yang dapat menimbulkan permusuhan pribadi maupun kelompok. Termasuk perkataan dan perbuatan tersebut yang ditujukan kepada seorang muslim atau non muslim. Tidak ada perbedaan status dalam melihat ciptaan tuhan, Islam melarang diskriminasi atas dasar apapun terutama terhadap sesama muslim. Islam sangat menjungjung tinggi hak asasi manusia dengan dasar penghargaan atas perbedaan.

\section{Penutup}

Dari pembahasan yang telah dilakukan di atas, faktor-faktor yang menjadi penyebab pelaku melakukan ujaran kebencian (hate speech)dalam media sosial yaitu, faktor dari dalam diri individu (internal) diantaranya yaitu keadaan psikologis dan kejiwaan individu dan faktor dari luar diri individu yaitu faktor lingkungan, faktor kurangnya kontrol sosial, faktor kepentingan masyarakat, faktor ketidaktahuan masyarakat, serta faktor sarana, fasilitas dan kemajuan teknologi. Akantetapi faktor yang paling sering menjadi penyebab pelaku melakukan kejahatan adalah faktor internal yaitu psikologis atau kejiwaan pelaku yaitu daya emosional yang tinggi, selain itu faktor sarana, fasilitas dan kemajuan teknologi juga sangat berpengaruh karena tersedianya sarana dan fasilitas yang mudah didapat dan kemajuan teknologi yang semakin canggih sehingga memudahkan setiap pengguna media sosial mengakses seluruh informasi tanpa batas.Dalam Islam, formulasi tindakan bate speech melebihi cakupan dalam definisi regulasi maupun istilah Barat. Asas moral yang mendasari hate speech berlaku bagi tindakan lain yang berkaitan dengan kemaslahatan umat. Pertama larangan untuk membenci orang lain, sesama muslim ataupun non muslim. Secara subjektif seorang muslim dilarang untuk memiliki perasaan hasad ataupun melakukan tindakan atas kebenciannya kepada orang lain. Adapun dari sudut objektif, maka tindakan apapun yang menyakiti orang lain dilarang oleh agama.

Berdasarkan kesimpulan diatas maka penulis menyarankan perlunya kerjasama lebih antara aparat penegak hukum, organisasi masyarakat dan masyarakat untuk melakukan pencegahan dan penanggulangan ke setiap daerah yang masyarakatnya masih belum paham dan mengetahui apa itu Ujaran Kebencian (Hate Speech) dan UndangUndang yang mengatur mengenai Ujaran Kebencian (Hate Speech) serta dampak yang ditimbulkan dari pelaku yang melakukan Ujaran Kebencian (Hate Speech) dalam media sosial. 


\section{Daftar Pustaka}

BakerAnton, Ahmad Charis Zubair, Metodologi Penelitian Filsafat, Yogyakarta: Kanisius, 1990

Bungin Burhan, Metodologi Penelitian Kualitatif, Jakarta: PT. Raja Grafindo Persada, 2008

Departemen Agama, Alquran dan Terjemahnya, Diponegoro, Bandung, 2010.

Departemen Pendidikan Nasional, Kamus Besar Bahasa Indonesia Pusat Bahasa, Jakarta: Gramedia Pustaka Utama, 2008.

Edward Aspinal, Titik. Tolak Reformasi; Hari-hari Terakbir Presiden Soeharto. Penerjemah A. Wisnu Hardana, Yogyakarta: LkiS, 2000.

Hanim Medira, "Hate Speech di Kalangan Generasi Modern" SH.Skrip, Institut Agama Islam Negeri Sunan Ampel, 2016.

Hasan M. Iqbal, Metodologi Penelitian dan Aplikasinya, Jakarta: Ghalia Indonesia, 2002.

Henri Septanto, Pengrub Hoax dan Ujaran Kebencian Sebuah Cyber Crime Dengan Teknologi Sederbana di Kebidupan Sosial Masyarakat, Jakarta Timur: Kalbis Cientia, 2018.

Imam Jalaluddin, Tafsir Jalalain, Bandung: Sinar Baru Algensindo, 2010.

Irianto Maladi Agus, Interaksionisme Simbolik: Pendekatan Antropologis Merespon Fenomena Keseharian, Semarang: Gigih Pustaka Mandiri, 2015.

Mery Febriyani, Analis Faktor Penyebab Pelaku Melakukan Ujaran Kebencian (hate speech), Lampung: Univ. Lampung, 2018.

MoloengLexy J, Metode Penelitian Kualitatif,Bandung: Remaja Karya, 1989.

Muhadjir Noeng, Metodologi Penelitian Kualitatif, Yogyakarta: Rake Sarasin, 1996

Nasrullah Rulli, Media sosial prespektif komunikasi, budaya, dan sosioteknologi, Bandung: Simbiosa Rekatama Media, 2017.

Nasution Harun, Metodologi Research, Jakarta: Bumi Aksara, 1996.

Salim dan Syahrum, Metodologi Penelitian Kualitatif, Jakarta: Citapustaka Media, 2007.

Soemantri Andara, Hate Speech Dan Pengarubnya Terbadap Mentalitas Elite Politik, SH.Skrip, Institut Agama Islam Negeri Sunan Ampel, 2014.

Sudarto, Metodologi Penelitian Filsafat, Jakarta: PT. Raja Grafindo Persada, 1996.

Suhariyanto Budi, Tindak Pidana Teknologi Informasi (CYBERCRIME), Jakarta: PT. Raja Grafindo Persada, 2014.

Sukmana Oman, Konsep dan Teori Gerakan Sosial, Malang: Intrans Publishing, 2016.

Sutan Remy Syahdeini, Kejahatan dan Tindak Pidana Komputer, Jakarta: Pustaka Utama Grafiti, 2009.

Zainuddin Ali, Hukum Pidana Islam, Jakarta: Sinar Grafika, 2007. 